\title{
Ultradilutions of Natrum muriaticum in the agronomic performance of cherry tomatoes submitted to saline stress
}

\author{
Ultradiluições de Natrum muriaticum no desempenho agronômico do tomateiro-cereja sob \\ estresse salino
}

\author{
Priscila Aparecida Faitanini Dandaro*, Filipe Pereira Giardini Bonfim, Aline Mako Yoshikawa, Lucas \\ Ferenzini Alves and Marisa Aida Diogo Matsinhe
}

Universidade Estadual Paulista, Botucatu, SP, Brasil. *Author for correspondence: prisciladandaro@hotmail.com.

Submission: 16/11/2018 / Acceptance: 01/07/2019

\begin{abstract}
Considered an agricultural input by the Ministry of Agriculture and Supply, homeopathy has been increasingly used in agriculture, especially in plants. It is an important technology to be adopted to reverse a framework of saline stress, because since the current procedures are little known, have hight costs and resources are not renewable. The present study aims to evaluate the effect of the homeopathic preparation Natrum muriaticum (Nat-m) on agronomic performance and physiological parameters of cherry tomatoes submitted to saline stress. The statistical design was a completely randomized design with eight treatments and five replications. The treatments consisted in the application of $N a t-m 3 \mathrm{cH}, 5 \mathrm{cH}, 7 \mathrm{cH}, 9 \mathrm{cH}$, $11 \mathrm{cH}, 13 \mathrm{cH}$ and two controls: etanol $70 \%$ and distilled water. They were conducted in a greenhouse and the treatments were applied weekly. Satisfactory results were observed with the applications of $N a t-m$ $11 \mathrm{cH}$ and $13 \mathrm{cH}$, with a significant increase in the characteristics such as height, diameter of the lap, number of leaves, number of flowers per cluster, number of fruits, fresh fruit mass, as well as on the productivity of tomato plants. Lower averages of the proline content were obtained with the application of these homeopathic preparations, this response may be associated with the osmotic adjustment promoted by the use of ultradiluitions. Natrum muriaticum positively affected the vegetative and reproductive development of cherry tomato plants submitted to saline stress.
\end{abstract}

KEYWORDS: salinity, homeopathic preparations, homeostasis, Solanum lycopersicon.

\section{RESUMO}

Considerada insumo agrícola pelo Ministério da Agricultura e do Abastecimento, a homeopatia vem sendo utilizada de forma crescente na agricultura, especialmente em plantas. É uma importante tecnologia a ser adotada para reversão de quadros de estresse salino, pois os procedimentos atuais são pouco conhecidos, possuem custos elevados e os recursos não são renováveis. O presente estudo objetivou avaliar o efeito do preparado homeopático Natrum muriaticum (Nat-m) no desempenho agronômico e parâmetros fisiológicos do tomateiro-cereja submetido à estresse salino. $O$ delineamento estatístico utilizado foi inteiramente casualizado, com oito tratamentos e cinco repetições. Os tratamentos consistiram na aplicação de $N a t-m 3 \mathrm{cH}, 5 \mathrm{cH}, 7 \mathrm{cH}, 9 \mathrm{cH}, 11 \mathrm{cH}, 13 \mathrm{cH}$ e duas testemunhas: etanol $70 \%$ e água destilada. Foram conduzidos em casa de vegetação e a aplicação dos tratamentos realizada semanalmente. Resultados satisfatórios foram obtidos com as aplicações de $N a t-m 11 \mathrm{cH}$ e $13 \mathrm{cH}, \mathrm{com}$ incremento significativo nas características altura, diâmetro de colo, número de folhas, número de flores por cacho, número de frutos, massa fresca de frutos, bem como na produtividade do tomateiro. Médias inferiores do teor de prolina foram obtidas com a aplicação destes preparados homeopáticos, tal resposta pode estar associada ao ajuste osmótico promovido pelo uso das ultradiluições. Natrum muriaticum atuou positivamente no desenvolvimento vegetativo e reprodutivo das plantas de tomate-cereja submetidas ao estresse salino.

PALAVRAS-CHAVE: salinidade, preparados homeopáticos, homeostase, Solanum lycopersicon.

\section{INTRODUCTION}

Salinity restricts growth by osmotic effect, water unavailability, toxicity, and/or nutritional disorder by altering the morphology, structure, and metabolism of plants, thereby inducing stress that affects plant 
development (VIANA et al. 2004). Hence, seed germination, seedling production, growth, productivity, and production quality can be compromised if the salinity tolerance is low (COSTA et al. 2001).

Tomato (Solanum lycopersicon L. var. Cerasiforme) is considered to be moderately sensitive to soil salinity, especially during its initial development (DOORENBOS \& KASSAM 1994). Several scientific studies have reported significant reduction in the growth and production of tomato in soils with high electrical conductivity (OLIVEIRA et al. 2007, MAGÁN et al. 2008, AL-BUSAIDI et al. 2009).

In some regions of Brazil such as the northeastern region where irrigated areas are affected by salinization (TÁVORA et al. 2001), or even in protected cultivation regions, it is necessary to measure the performance of the plant species exposed to this condition and consider the adoption of practices that aim at better management of crops, especially the recovery of saline soils. The recovery of saline or alkaline soils facilitate chemical, physical, and biological conditions that guarantee seed germination, plant growth, and economic production. However, it is more important to prevent the irrigated soils from becoming degraded and unproductive than simply recovering them (CAVALCANTE et al. 2002). Although the recovery of saline soils is technically possible, it is a slow and very expensive process (DINIZ 1995). Therefore, it is necessary to develop new technologies.

Homeopathy is one of the technology options that facilitate the development of plant species in highsalinity conditions. It was officialized as an agricultural input by the Ministry of Agriculture and Supply, in Normative Instruction No. 7, published in the Official Gazette of the Union 19/05/1999. The use of homeopathic preparations in agriculture, especially in plants, has been in great demand. When homeopathy is applied under stress conditions, the plants respond intensely to this technology (CASALI et al. 2002).

Homeopathy was discovered in 1796 by the German physician, Samuel Hahnemann. However, homeopathic experiments on plants started at the Institute of Biology (Stuttgart, Germany) in 1920. Homeopathy is the study of the ultradilutions that access the self-regulation of living systems by resonance, based on the principle of similarity. Homeopathic preparations are tested in healthy organisms to observe signs that will serve as guidance in treatments. In the soil, only physical, chemical, and biological quality indicators indicate the pathogenesis of homeopathic preparations (ANDRADE et al. 2001).

The response of plants to salinity conditions is related to the expression of several genes (ZHU 2001) as well as salt tolerance levels that depend on the concentration and nature of the dissolved salts, climatic factors, water absorption, and plant nutrition. However, these factors may be different based on the species (MOURA et al. 2003).

Natrum muriaticum (Nat-m) is the recommended homeopathic preparation for plants grown under stress conditions (BONATO et al. 2006), as it improves the development and acclimatization of plants in areas that are unsuitable for growth. Meanwhile, experimentation, which is one of the principles of homeopathy, is performed whenever necessary, to discover the potential of homeopathic preparations. However, there is insufficient knowledge about the physiological mechanisms of the performance and the methods of ultradilutions in vegetables.

Thus, this study evaluates the action of Nat-m on the agronomic performance and physiological responses of cherry tomatoes subjected to saline stress, to identify a possible alternative facilitator for the development of plants in expropriated environments.

\section{MATERIAL AND METHODS}

The experiment was performed in a protected environment (greenhouse) at the Experimental Farm Lageado in the premises of the Department of Horticulture, Faculty of Agronomic Sciences, São Paulo State University Júlio de Mesquita Filho (UNESP) - Botucatu campus $\left(22^{\circ} 51^{\prime} \mathrm{S}, 48^{\circ} 26^{\prime} \mathrm{W}\right.$; altitude $786 \mathrm{~m}$ ), from May to September, 2016.

Cherry tomatoes seedlings from a commercial seed brand without treatment were transplanted into 10 $\mathrm{dm}^{3}$ pots previously filled with soil. Soil correction was performed with limestone and corral-tanned manure ( $30 \mathrm{t} \mathrm{ha}^{-1}$, converted to the pot volume), and a sample was sent to the FCA/UNESP Soil Fertility Laboratory for chemical analysis (Table 1).

For soil salinization, $1.461 \mathrm{~g} \mathrm{~L}^{-1}$ of $\mathrm{NaCl}$ solution with an electrical conductivity of $2.5 \mathrm{dS} \mathrm{m}^{-1}$ was used, where the volume corresponded to the field capacity (FC) of the substrate. To determine the FC of the substrate, five $100 \mathrm{~g}$ samples of the prepared substrate previously dried at $105^{\circ} \mathrm{C}$ for $24 \mathrm{~h}$ were used. These samples were saturated with $250 \mathrm{~mL}$ of water and the average non-percolated water volumes after $24 \mathrm{~h}$ in each of the samples were used as FC. This value was extrapolated to the amount of substrate used in the culture vessels, adjusting to a $100 \%$ FC. The value determined was $3.050 \mathrm{~mL}$ for each vessel of $\mathrm{NaCl}$ solution added for soil salinization. 
Table 1. Results of soil chemical analysis. Botucatu, SP, 2016.

\begin{tabular}{|c|c|c|c|c|c|c|c|c|c|c|c|c|}
\hline Sample & $\begin{array}{c}\mathrm{pH} \\
\mathrm{CaCl}_{2}\end{array}$ & $\begin{array}{c}\text { M.O } \\
\mathrm{g} / \mathrm{dm}^{3}\end{array}$ & $\begin{array}{l}\text { resin } \mathrm{P} \\
\mathrm{mg} / \mathrm{dm}^{3}\end{array}$ & $\mathrm{Al}$ & $\mathrm{H}+\mathrm{Al}$ & $\mathrm{K}$ & $\begin{array}{c}\mathrm{Ca} \\
\mathrm{mmol}\end{array}$ & $\begin{array}{l}\mathrm{Mg} \\
/ \mathrm{dm}^{3}\end{array}$ & SB & CTC & V\% & $\begin{array}{c}\mathrm{S} \\
\mathrm{mg} / \mathrm{dm}^{3}\end{array}$ \\
\hline 1 & 6.7 & 19 & 269 & 0 & 8 & 2.6 & 15 & 19 & 37 & 45 & 82 & 170 \\
\hline Sample & & B & & & $\mathrm{Cu}$ & $\mathrm{ms}$ & $\begin{array}{c}\mathrm{Fe} \\
\mathrm{g} / \mathrm{dm}^{3}\end{array}$ & & & $\mathrm{Mn}$ & & $\mathrm{Zn}$ \\
\hline 1 & & 0.46 & & & 2.2 & & 19 & & & 5.5 & & 6.6 \\
\hline
\end{tabular}

The irrigation control was performed using gravimetric method, where water was added until the mass of the substrates in the vessels reached the value previously determined, based on soil mass and water mass. Moreover, the experimental plots were monitored daily to ensure that they are maintained at $100 \%$ FC. The transplant was performed on the $32 n d$ day, and each week thereafter, shoots were removed. All the plants were kept with two main stems, being tutored at day 44 with the aid of strings and wires fixed at $1.7 \mathrm{~m}$ from the floor.

The plant decapitation or apical pruning was realized in the plants that exceeded the wire used in the tutoring. Meanwhile, it was not necessary to realize phytosanitary control, as the presence of pests and/or pathogens were not observed throughout the study.

Furthermore, Nat- $m$ was prepared from sea salt and applied based on the principles of similarity and minimum doses. From the standpoint of the similarity principle, high soil salinity levels have deleterious effects on the plants, due to the presence of sodium and particularly, sodium chloride $(\mathrm{NaCl})$ salt (CHANDRASHEKAR \& SANDHYARANI 1996).

Thus, eight treatments were proposed: $N a t-m(3 \mathrm{cH}, 5 \mathrm{cH}, 7 \mathrm{cH}, 9 \mathrm{cH}, 11 \mathrm{cH}$, and $13 \mathrm{cH})$, Control 1 (ethanol 70\%), and Control 2 (distilled water), based on plant chart indications in crops on soils with saline tendencies (CASALI et al. 2009).

The homeopathic preparations were purchased from a qualified homeopathic pharmacy in Botucatu, São Paulo, Brazil.

The design was completely randomized, with eight treatments and five repetitions, totaling 40 experimental plots, where each plot consists of one plant. The treatments consisted of the application of Nat$m(3 \mathrm{cH}, 5 \mathrm{cH}, 7 \mathrm{cH}, 9 \mathrm{cH}, 11 \mathrm{cH}$, and $13 \mathrm{cH})$ and two controls (Control 1: $70 \%$ ethanol without dynamization, and Control 2: distilled water without dynamization).

The treatments was applied by adding five drops of each treatment solution in $250 \mathrm{~mL}$ of water and distributing $50 \mathrm{~mL}$ of this solution in each repetition, in the soil around the plant. A self-developed method was used in the experiment. In the first week, the plants received the treatments daily. During the second week, the applications were performed with an interval of one day and so forth, with the increase in the number of days of interval per week. After the fifth week, the number of days of interval per week decreased until daily application, and this schedule was repeated until the end of the experiment.

The evaluated characteristics were height $(\mathrm{cm})$, lap diameter $(\mathrm{mm})$, number of leaves, number of flowers per cluster, number of fruits, number of fruits per cluster, chlorophyll-a fluorescence, stomatal conductance, relative water content, hydric potential, leaf area determination, fresh fruit phytomass determination (grams), soluble solid content ( $\left.{ }^{\circ} \mathrm{Brix}\right)$, and proline content of cherry tomato plant.

\section{Height of plants}

The height of the plants (in $\mathrm{cm}$ ) was determined on the 150th day after transplanting the seedlings, using a tape measure. Its value corresponded to the distance between the base at the ground and the apex of the plant.

\section{Lap diameter}

The lap diameter (in $\mathrm{mm}$ ) was measured on the 150th day after transplanting the seedlings. Its value was obtained through the stem of the plants, at the basal region, and close to the ground, using a digital caliper.

\section{Number of leaves, flowers, and fruits}

The numbers of leaves and flowers were evaluated on the 100th day. The fruit evaluation started on the 120th day and ended on the 150th day after transplanting the seedlings. These characteristics were evaluated by direct counting using nondestructive analysis.

\section{Determination of fresh fruit mass and soluble solids ( $\left.{ }^{\circ} \mathrm{Brix}\right)$ of fruits}

The mass of the fresh fruit was determined using a digital scale, where the total weight of fruits per plot was calculated by the sum of all the harvests. Harvesting started on the 120th day and ended on the 
150th day after transplanting the seedlings. Meanwhile, harvesting, weighing of fresh fruit mass, and determination of soluble solids were performed daily during this period.

The soluble solid content was determined directly from the tomato pulp at room temperature by refractometry, using a portable manual refractometer (Atago) with a 0 32\% ${ }^{\circ}$ Brix scale.

\section{Determination of leaf area}

Ten discs with $8 \mathrm{~mm}$ diameter leaflets of the new fully expanded leaf were extracted on the 120th day after transplanting the seedlings. The discs were kept in air-circulation greenhouses at $65^{\circ} \mathrm{C}$ for $24 \mathrm{~h}$. The average mass of the ten discs represented an area of $0.5 \mathrm{~cm}^{2}$. The leaf area was estimated using the photomass of the dry leaves (PRASAD et al. 1994).

\section{Relative water content}

Three evaluations of the relative water content of the plants were performed. However, 10 discs with $8 \mathrm{~mm}$ diameter were removed from the plants and weighed on a precision analytical scale to obtain the weight of the fresh material. The discs were placed in small flasks containing $10 \mathrm{~mL}$ of distilled water, and then placed in a refrigerator for $24 \mathrm{~h}$. Afterwards, the surfaces of the discs were dried using tissue paper and weighed again to obtain the weight of the saturated material. The discs were then brought into an oven $\left(65^{\circ} \mathrm{C}\right)$, until a constant weight that characterized the weight of the dried material was obtained.

The relative water content was calculated using Eq. (1) (BARRS \& WEATHERLEY 1962):

$$
R W C(\%)=\left[\frac{F W-D W}{T W-D W}\right] \times 100
$$

where,

RWC: relative water content in the leaf (\%),

FW: initial fresh weight $(\mathrm{g})$,

DW: dry weight at $65^{\circ} \mathrm{C}(\mathrm{g})$,

TW: turgid fresh weight $(\mathrm{g})$.

\section{Chlorophyll-a fluorescence}

Chlorophyll-a fluorescence was evaluated on the 120th day after transplanting the seedlings, to determine the effective quantum yield $(\mathrm{Y}(\mathrm{II})$ ), electron transport rate (ETR), non-photochemical dissipation (NPQ), initial fluorescence (Fo), maximum fluorescence (Fm), and maximum quantum efficiency of photosystem II (Fv/Fm), using Junior-PAM Chlorophyll Fluorometer (Walz, Germany).

\section{Stomatal conductance}

The stomatal conductance was evaluated on the 120th day after transplanting the seedlings, to determine the stomatal conductance $\left(\mathrm{mmol} \mathrm{m} \mathrm{m}^{-2} \mathrm{~s}^{-1}\right)$ and the vapor pressure deficit (DPVar), using Leaf Porometer Model SC-1 (Decagon, USA) in a balanced equilibrium state.

\section{Water potential}

The water potential was evaluated on the 120th day after transplanting the seedlings. A leaflet was obtained from each plant and evaluated using Water Potential Analyzer with Temperature Controller, WP4-T (Decagon / USA).

\section{Determination of proline content}

The method described by TORELLO \& RICE (1986) was adapted, where $0.5 \mathrm{~g}$ of fresh leaves were obtained from the treatments on the 150th day after the seedlings were transplanted. The samples were macerated with liquid nitrogen, and $10 \mathrm{~mL}$ of $3 \%$ sulfosalicylic acid were added to the samples and homogenized. The extracts obtained were transferred to Falcon tubes and subjected to centrifugation at $6500 \mathrm{G}$ for $20 \mathrm{mins}$ at $20{ }^{\circ} \mathrm{C}$. Moreover, aliquots of $0.5 \mathrm{~mL}$ of supernatant solution were transferred to test tubes while $0.5 \mathrm{~mL}$ of acid ninhydrin and $0.5 \mathrm{~mL}$ of glacial acetic acid p.a. were added to the mixture. The reaction mixture was left for 25 mins in a boiling bath and cooled in an ice bath for 5 mins to realize vortex homogenization. The color intensity was measured at $520 \mathrm{~nm}$ in a spectrophotometer. The absorbances obtained were then adjusted in the line equation obtained by the calibration curve made with standard L-Proline. The results are expressed in micrograms of proline per gram of fresh matter.

\section{Statistical analysis}

Variance analysis was performed on the data and the average values were compared using ScottKnott test at $1 \%$ probability level in ASSISTAT 7.7 software.

\section{RESULTS AND DISCUSSION}

At $p<0.05$, the variance analysis on the characteristics evaluated showed significant differences as a function of the treatments, thereby validating the action of Nat-m under experimental conditions. 
The use of Nat-m $11 \mathrm{cH}$ and $13 \mathrm{cH}$ enhanced the performance of all evaluated variables, except for number of fruits per cluster and soluble solid content, presenting statistical difference in relation to the treatments $\mathrm{Nat}-\mathrm{m} 3 \mathrm{cH}, 7 \mathrm{cH}, 9 \mathrm{cH}$ as well as Control 1 and Control 2. This enhanced the vegetative and reproductive development of cherry tomato plants subjected to saline stress (Tables 2 and 3 ).

Moreover, Nat- $m 5 \mathrm{cH}$ showed higher mean values for height $(\mathrm{cm})$, lap diameter $(\mathrm{mm})$, number of leaves, and number of flowers per cluster, in comparison with $\mathrm{Nat}-\mathrm{m} 3 \mathrm{cH}, 7 \mathrm{cH}, 9 \mathrm{cH}$ as well as Control 1 and Control 2, as they are statistically different (Table 2). Similarly, the pelletization of $\mathrm{Nat}-\mathrm{m} 5 \mathrm{cH}$ and $7 \mathrm{cH}$ enhanced the production of healthy tomato seedlings when subjected to saline stress (BONFIM et al. 2012).

Table 2. Mean values of height $(\mathrm{cm})$, lap diameter $(\mathrm{mm})$, number of leaves $(\mathrm{NL})$, and number of flowers per cluster of cherry tomato grown under saline stress and subjected to different Nat-m dynamizations. Botucatu, SP, 2016.

\begin{tabular}{|c|c|c|c|c|}
\hline Treatments & Height & lap D & $\mathrm{NL}$ & N. flowers/cluster \\
\hline Nat-m 3cH & $67.60 \mathrm{~b}$ & $16.32 \mathrm{~b}$ & $17.00 \mathrm{~b}$ & $6.33 \mathrm{~b}$ \\
\hline Nat-m $5 \mathrm{cH}$ & $152.60 \mathrm{a}$ & $12.42 \mathrm{a}$ & $23.60 \mathrm{a}$ & $8.85 a$ \\
\hline Nat-m 7cH & $73.20 \mathrm{~b}$ & $15.72 b$ & $17.00 \mathrm{~b}$ & $6.56 \mathrm{~b}$ \\
\hline Nat-m 9cH & $95.40 \mathrm{~b}$ & $17.96 \mathrm{~b}$ & $22.60 \mathrm{~b}$ & $6.58 \mathrm{~b}$ \\
\hline Nat-m $11 \mathrm{cH}$ & $192.60 \mathrm{a}$ & $21.68 \mathrm{a}$ & $35.00 \mathrm{a}$ & $9.20 \mathrm{a}$ \\
\hline Nat-m $13 \mathrm{cH}$ & $197.00 \mathrm{a}$ & $23.88 \mathrm{a}$ & $30.20 a$ & $9.35 \mathrm{a}$ \\
\hline Ethanol $70 \%$ & $93.80 \mathrm{~b}$ & $16.64 \mathrm{~b}$ & $10.80 \mathrm{~b}$ & $7.45 b$ \\
\hline Distilled water & $90.80 \mathrm{~b}$ & $16.30 \mathrm{~b}$ & $17.60 \mathrm{~b}$ & $7.12 \mathrm{~b}$ \\
\hline $\mathrm{CV}(\%)$ & 55.16 & 51.37 & 54.20 & 55.02 \\
\hline
\end{tabular}

The averages followed by at least one same letter in the column do not differ significantly from one to another by the Scott-Knott test at $1 \%$ probability.

By means of self-regulation, the plants respond very intensely to homeopathy aimed at overcoming stress situations (CASALI et al. 2009). The loss of Homeostasis by plants is indicative of disruption of its vital energy and the symptoms observed are attempts to recover the energy balance. Homeopathic preparations therefore promote homeostasis of systemic form, providing the entire balance (BONFIM 2011).

The increase in the number of fruits produced by $N a t-m 11 \mathrm{cH}$ and $13 \mathrm{cH}$ showed a direct relation with the fresh fruit mass; the use of Nat-m $11 \mathrm{cH}$ increased $195.81 \%$ and $85.77 \%$ compared to that of controls 1 and 2, respectively; the use of $13 \mathrm{cH}$ showed increases of $196.51 \%$ and $86.21 \%$ for controls 1 and 2 , respectively (Table 3 ).

Table 3. Mean number of fruits (NF), number of fruits per cluster (NF/cluster), fresh fruit mass (MFF) in grams, soluble solid content ( $\left.{ }^{\circ} \mathrm{BRIX}\right)$ and proline content (PROL; $\mu \mathrm{g} \mathrm{g}^{-1}$ ) of cherry tomato plants grown under saline stress and subjected to different Nat-m dynamizations. Botucatu, SP, 2016.

\begin{tabular}{lrccll}
\hline Treatments & NF & NF/cluster & MFF & ${ }^{\circ}$ BRIX & PROL \\
\hline Nat- $m$ 3cH & $61.20 \mathrm{~b}$ & $5.40 \mathrm{a}$ & $684.9 \mathrm{~b}$ & $3.78 \mathrm{a}$ & $24.56 \mathrm{a}$ \\
Nat- $m 5 \mathrm{cH}$ & $139.60 \mathrm{~b}$ & $6.31 \mathrm{a}$ & $1228.4 \mathrm{~b}$ & $6.70 \mathrm{a}$ & $23.75 \mathrm{a}$ \\
Nat $-\mathrm{m} 7 \mathrm{cH}$ & $79.80 \mathrm{~b}$ & $5.80 \mathrm{a}$ & $679.73 \mathrm{~b}$ & $3.81 \mathrm{a}$ & $32.57 \mathrm{a}$ \\
Nat- $m$ 9cH & $70.00 \mathrm{~b}$ & $5.54 \mathrm{a}$ & $583.03 \mathrm{~b}$ & $6.03 \mathrm{a}$ & $28.98 \mathrm{a}$ \\
Nat $-\mathrm{m} 11 \mathrm{cH}$ & $169.80 \mathrm{a}$ & $6.31 \mathrm{a}$ & $1558.38 \mathrm{a}$ & $6.37 \mathrm{a}$ & $12.58 \mathrm{~b}$ \\
Nat- $m 13 \mathrm{cH}$ & $170.20 \mathrm{a}$ & $7.97 \mathrm{a}$ & $2030.01 \mathrm{a}$ & $6.22 \mathrm{a}$ & $16.31 \mathrm{~b}$ \\
Ethanol $70 \%$ & $57.40 \mathrm{~b}$ & $5.38 \mathrm{a}$ & $474.86 \mathrm{~b}$ & $4.10 \mathrm{a}$ & $33.24 \mathrm{a}$ \\
Distilled water & $91.40 \mathrm{~b}$ & $5.50 \mathrm{a}$ & $735.39 \mathrm{~b}$ & $5.43 \mathrm{a}$ & $36.54 \mathrm{a}$ \\
\hline CV $\%$ \% & 58.34 & 37.32 & 62.12 & 44.21 & 26.54 \\
\hline
\end{tabular}

The averages followed by at least one same letter in the column do not differ significantly from one to another by the Scott-Knott test at $1 \%$ probability.

In addition, Nat- $m 11 \mathrm{cH}$ and $13 \mathrm{cH}$ produced $124.67 \mathrm{t} \mathrm{ha}^{-1}$ and $162 \mathrm{t} \mathrm{ha}^{-1}$ of cherry tomato under experimental conditions, respectively, while Control 1 and Control 2 produced $37.98 \mathrm{t} \mathrm{ha}^{-1}$ and $58.83 \mathrm{t} \mathrm{ha}^{-1}$, 
respectively. Thus, $N a t-m 11 \mathrm{cH}$ and $13 \mathrm{cH}$ achieved a similar productivity to those recommended by the Brazilian Horticulture Association, where the productivity of cherry tomato can reach up to $150 \mathrm{tha}^{-1}$.

A significant effect of the soluble solid content could be verified through variance analysis at $p<0.05$. However, there were no statistical differences among treatments by the Scott-Knott test. Thus, higher averages were observed in $\mathrm{Nat}-\mathrm{m} 5 \mathrm{cH}, 11 \mathrm{cH}$, and $13 \mathrm{cH}$ treatments (Table 3).

Meanwhile, lower averages of proline content were observed in $N a t-m 11 \mathrm{cH}$ and $13 \mathrm{cH}$, as they statistically differed from other treatments (Table 3). These responses may be associated with the osmotic adjustment promoted by the use of ultradilutions. In this process, plants that are subjected to these treatments do not need to interrupt protein synthesis or accumulate the amino acid produced. Thus, they are characterized as less-stressed plants. These results corroborate with the results obtained by SANTA-CRUZ et al. (1998), AZIZ et al. (1999), and ALIAN et al. (2000), where they observed that there is an increase in the proline content of tomato leaves, based on the increase of the salinity of the medium.

The proline content in Control 1 and Control 2 increased by $164.22 \%$ and $190.46 \%$, respectively, in comparison with Nat- $m 11 \mathrm{cH}$ treatment. By contrast, the proline content in Control 1 and Control 2 increased by $103.80 \%$ and $124.03 \%$, respectively, in comparison with $\mathrm{Nat}-\mathrm{m} 13 \mathrm{cH}$ treatment. These results are similar to the results obtained for Tanacetum parthenium treated with $N a t-m 2 \mathrm{cH}$ and subsequently subjected to water stress (65\% FC), where no significant accumulations of proline were observed in Tanacetum parthenium when compared to the control (CARVALHO et al. 2004).

At the same time, the 10 tomato species cultivated in nutrient solution with $\mathrm{NaCl}$, including $L$. esculentum var. cerasiforme and L. esculentum "DUKE," exhibited increases in the proline content in the leaves, which was 11-116 times greater than the value obtained for control treatment without addition of $\mathrm{NaCl}$ (RAJASEKARAN et al. 2000).

Proline is the most studied molecule in plants subjected to abiotic stresses, owing to its importance in osmotic adjustment (HEUER 1994, MADAN et al. 1995). Under the influence of stress, protein synthesis is inhibited and protein degradation is accelerated, which leads to an accumulation of free amino acids and amines. A major factor that inhibits protein metabolism is the change in the proportions of amino acids and an occasional increase in proline concentration (LARCHER 2006).

Furthermore, no significant differences were observed at $p<0.05$ for the characteristics related to photosynthetic development such as stomatal conductance, DPVar, Y(II), ETR, Fm, Fv/Fm, RWC, leaf area, and water potential, when Nat-m was applied in cherry tomatoes that were subjected to saline stress. The values for each treatment are presented in Tables 4, 5, and 6.

Table 4. Mean values of stomatal conductance $\left(\mathrm{mmol} \mathrm{m}^{-2} \mathrm{~s}^{-1}\right)$ and vapor pressure deficit (DPVar) of cherry tomato plants grown under saline stress and subjected to different Nat-m dynamizations. Botucatu, SP, 2016.

\begin{tabular}{lcc}
\hline Treatments & Conductance & DPVar \\
\hline Nat- $m$ 3cH & 177.14 & 1.82 \\
Nat- $m 5 \mathrm{cH}$ & 248.28 & 2.35 \\
Nat- $m$ 7cH & 141.99 & 1.84 \\
Nat $-m$ $9 \mathrm{cH}$ & 287.10 & 2.11 \\
Nat- $m 11 \mathrm{cH}$ & 207.87 & 2.39 \\
Nat $-\mathrm{m} 13 \mathrm{cH}$ & 245.35 & 2.18 \\
Ethanol $70 \%$ & 174.99 & 2.40 \\
Distilled water & 174.99 & 2.36 \\
\hline CV $(\%)$ & 42.26 & 17.42 \\
\hline
\end{tabular}

Data not significant by the $\mathrm{F}$ test at $5 \%$ probability.

However, the application of $\mathrm{Nat}-\mathrm{m} 5 \mathrm{cH}, 9 \mathrm{cH}, 11 \mathrm{cH}$, and $13 \mathrm{cH}$ facilitated higher stomatal conductance in plants subjected to high salinity level, in comparison with Control 1 and Control 2, which did not differ statistically by $F$ test. DOWNTON (1977), PRIOR et al. (1992), and LUDDERS \& GOLOMBEK (1993) reported that the increase in salinity levels promotes a reduction in stomatal conductance, which leads to a decrease in the intercellular $\mathrm{CO}_{2}$ partial pressure. Consequently, there is a negative interference in the assimilation of $\mathrm{CO}_{2}$ by the photosynthetic apparatus, compromising the performance of the plants subjected to this adverse condition.

As for the vapor pressure deficit, the application of Control 1 and 2 presented higher averages compared to the other treatments (Table 4). Some authors have verified that this increase, when there is 
saline stress in the plant, reduces the flow of water vapor from the interior of the sub-stomatal chamber to the atmosphere, causing a reduction in transpiration (THOMAS \& GAUSLING 2000). Inhibition of this process, associated with others, can cause considerable reduction in productivity and quality of production.

Table 5. Mean values of the effective quantum yield $(\mathrm{Y}(\mathrm{II}))$, electron transport rate (ETR), non-photochemical dissipation (NPQ), initial fluorescence (Fo), maximum fluorescence (Fm) and maximum quantum efficiency of photosystem II (Fv/Fm) of cherry tomato plants grown under saline stress and subjected to different Nat-m dynamizations. Botucatu, SP, 2016.

\begin{tabular}{|c|c|c|c|c|c|c|}
\hline Treatments & $\mathrm{Y}(\mathrm{II})$ & ETR & NPQ & Fo & Fm & $\mathrm{Fv} / \mathrm{Fm}$ \\
\hline Nat-m 3cH & 0.17 & 95.9 & 1459.56 & 190.66 & 593.6 & 0.66 \\
\hline Nat-m $5 \mathrm{cH}$ & 0.24 & 76.4 & 984.31 & 200.26 & 638.73 & 0.67 \\
\hline Nat-m 7cH & 0.17 & 61.58 & 1176.57 & 242.53 & 731.06 & 0.65 \\
\hline Nat-m 9cH & 0.14 & 52.7 & 916.8 & 240.8 & 660.13 & 0.6 \\
\hline Nat-m $11 \mathrm{cH}$ & 0.21 & 57.29 & 1790.78 & 226.13 & 641.06 & 0.63 \\
\hline Nat $-m 13 \mathrm{cH}$ & 0.17 & 49.28 & 1109.76 & 224.8 & 647.86 & 0.64 \\
\hline Ethanol $70 \%$ & 0.2 & 54.13 & 1018.58 & 210.55 & 707.86 & 0.69 \\
\hline Distilled water & 0.21 & 68.9 & 1019.29 & 203.26 & 618.13 & 0.65 \\
\hline $\mathrm{CV}(\%)$ & 26.52 & 36.09 & 63.54 & 19.95 & 20.7 & 9.97 \\
\hline
\end{tabular}

Data not significant by the $\mathrm{F}$ test at $5 \%$ probability.

Table 6. Mean values of leaf area $\left(\mathrm{cm}^{2}\right)$, relative water content (RWC), and water potential of cherry tomato plant grown under saline stress and subjected to different Nat-m dynamizations. Botucatu, SP, 2016.

\begin{tabular}{lclc}
\hline Treatments & Leaf area & RWC & Water Potential \\
\hline Nat $-m 3 \mathrm{cH}$ & 15.88 & 83.74 & 1.66 \\
Nat $-m 5 \mathrm{cH}$ & 18.58 & 67.2 & 1.94 \\
Nat $-m$ $7 \mathrm{cH}$ & 11.83 & 67.97 & 1.95 \\
Nat $-m$ $9 \mathrm{cH}$ & 18.21 & 67.77 & 2.00 \\
Nat $-m 11 \mathrm{cH}$ & 19.85 & 63.71 & 1.95 \\
Nat $-m 13 \mathrm{cH}$ & 28.7 & 63.3 & 1.73 \\
Ethanol $70 \%$ & 14.27 & 74.22 & 1.91 \\
Distilled water & 14.23 & 63.66 & 1.85 \\
\hline CV $(\%)$ & 68.58 & 25.7 & 14.47
\end{tabular}

Data not significant by the $\mathrm{F}$ test at $5 \%$ probability.

Extreme conditions of environmental stress such as salinity can affect thylakoid events, thereby interfering with the efficiency of photosynthesis and inactivating photosystem II (P680) as well as the electron transport chain that would produce ATP and NADPH (COSTA et al. 2003, BAKER \& ROSENQVIST 2004).

Photochemical efficiency of photosynthesis is obtained by determination of different chlorophyll-a fluorescence variables. The main variables observed in chlorophyll-a fluorescence measurements are initial fluorescence $(F o)$, maximum fluorescence $(F m)$, variable fluorescence $(F v)$, maximum quantum yield of photosystem II (Fv / Fm), and relative rate of electron transport (ETR) (OLIVEIRA 2005).

In this study, we can verify that the parameters related to chlorophyll-a fluorescence did not efficiently detect significant differences among the treatments under the imposed conditions (Table 5). Such responses may be associated with the method of determining these characteristics, because they were realized only 120 days after transplanting the seedlings. Thus, plant homeostasis could have occurred during that period.

The Control $1\left(14.27 \mathrm{~cm}^{2}\right)$ and Control $2\left(14.23 \mathrm{~cm}^{2}\right)$ treatments presented a significant reduction in the leaf area compared to $N a t-m 13 \mathrm{cH}$ treatment $\left(28.7 \mathrm{~cm}^{2}\right.$ ), although they did not differ statistically (Table 6). MUNNS (2002) reported that leaf area reduction is associated with reduced plant leaf size when it is exposed to high salinity. The change in turgor caused by high osmotic pressure in the root zone promotes changes in the permeability of cell membranes, caused by toxic ions in the internerval spaces and cell wall, thereby resulting in decreased cell division and cell elongation.

There was no significant change in the average values of the relative water content and water potential, based the treatments used in this study. 


\section{CONCLUSION}

Natrum muriaticum has a positive impact on the vegetative and reproductive development of cherry tomato plants subjected to saline stress, thereby causing low interference in the physiology of the plant, having Natrum muriaticum $11 \mathrm{cH}$ and $13 \mathrm{cH}$ superiority in the means of the evaluated characteristics.

\section{ACKNOWLEDGEMENTS}

We appreciate the National Council for Scientific and Technological Development (CNPq) for financial support rendered in performing the experiment.

\section{REFERENCES}

AL-BUSAIDI A et al. 2009. Response of different tomato cultivars to diluted seawater salinity. Asian Journal of Crop Science 1: 77-86.

ALIAN A et al. 2000. Genotypic difference in salinity and water stress tolerance of fresh market tomato cultivars. Plant Science 152: 59-65.

ANDRADE FMC et al. 2001. Efeito de homeopatias no crescimento e na produção de cumarina em chambá (Justicia pectoralis Jacq.). Revista Brasileira de Plantas Medicinais 4: 19-28.

AZIZ A et al. 1999. Salt stress-induced proline accumulation and changes in tyramine and polyamine levels are linked to ionic adjustment in tomato leaf discs. Plant Science 145: 83-91.

BAKER NR \& ROSENQVIST E. 2004. Applications of chlorophyll fluorescence can improve crop production strategies: an examination of future possibilities. Journal of Experimental Botany 55: 1607-1621.

BARRS HD \& WEATHERLEY PE. 1962. A re-examination of the Relative Turgidity Technique for estimating water deficits in leaves. Australian Journal of Biological Sciences 15: 413- 428.

BONATO CM et al. 2006. Homeopatia simples: alternativa para a agricultura familiar. 1.ed. Marechal Cândido Rondon: Líder. 32p.

BONFIM FPG. 2011. Altas diluições em vegetais submetidos a estresse: por alumínio, salino e hídrico. Tese (Doutorado em Fitotecnia). Viçosa: UFV. 54p.

BONFIM FPG et al. 2012. Germinacão e vigor de sementes de tomate (Lycopersicon esculentum, Mill) peletizadas com preparados homeopáticos de Natrum muriaticum, submetidas a estresse salino. Enciclopédia Biosfera 8: 625-633.

CARVALHO LM et al. 2004. Efeito da homeopatia na recuperação de plantas de artemísia [Tanacetum parthenium (L.) Schultz-Bip] submetidas à deficiência hídrica. Revista Brasileira de Plantas Medicinais 6: 20-27.

CASALI VWD et al. 2002. Pesquisa sobre homeopatia nas plantas. In: 3 Seminário Brasileiro Sobre Homeopatia na Agropecuária Orgânica. Resumos... Viçosa: UFV. p.16-25.

CASALI VWD et al. 2009. Acologia de altas diluições. Viçosa: UFV. 537p.

CAVALCANTE LF et al. 2002. Melhoria química e física de um solo salino sódico tratado com matéria orgânica e cultivado com leguminosas forrageiras. Revista Ciência Agrícola 6: 27-35.

CHANDRASHEKAR KR \& SANDHYARANI S. 1996. Salinity induced chemical changes in Crotalaria striata dc. plants. Indian Journal of Plant Physiology 1: 44-48.

COSTA ES et al. 2003. Chlorophyll a fluorescence analysis in response to excitation irradiance lin bean plants (Phaseolus vulgaris L. and Vigna unguiculata L. Walp) submitted to high temperature stress. Photosynthetica 41: 7782.

COSTA JRM et al. 2001. Caracterização dos frutos de maracujá amarelo irrigados com água salina. Revista Brasileira de Engenharia Agrícola e Ambiental 5: 143-146.

DINIZ IA. 1995. Cultivo de feijão guandu (Cajanus cajan) em solo salinizado tratado com matéria orgânica e drenagem. Dissertação (Mestrado em Produção Vegetal). Areia: UFPB. 50p.

DOORENBOS J \& KASSAM AH. 1994. Efeito da água no rendimento das culturas. Campina Grande: UFPB. 306p. (Estudos FAO: Irrigação e Drenagem, 33).

DOWNTON WJS. 1976. Photosynthesis in salt-stressed grapevines. Australian Journal of Plant Physiology 4: 183-192.

HEUER B. 1994. Osmoregulatory role of proline in water and salt-stressed plants. In: PESSARAKLI M. (Ed.). Handbook of Plant and Crop Stress. New York: Marcel Dekker Inc. p.363-381.

LARCHER W. 2006. Ecofisiologia vegetal. São Carlos: RIMA. 530p.

LUDDERS P \& GOLOMBEK SD. 1993. Effects of short-term salinity on leaf gas exchange of the fig (Ficus carica L.). Plant and Soil 148: 21-27.

MADAN S et al. 1995. Proline and proline metabolizing enzymes in in-vitro selected NaCl-tolerant Brassica juncea L. under salt stress. Annals of Botany 76: 51-57.

MAGÁN JJ et al. 2008. Effects of salinity on fruit yield and quality of tomato grown in soil-less culture in greenhouses in Mediterranean climatic conditions. Agricultural Water Management 95: 1041-1055.

MOURA GED et al. 2003. Efeito do $\mathrm{NaCl}$ sobre a multiplicação in vitro de bananeiras da variedade Grand naine. In: 5 Encontro nacional de biólogos. Resumos... Natal. p.74.

MUNNS R. 2002. Comparative physiology of salt and water stress. Plant, Cell and Environment 25: 239-250.

OLIVEIRA BC et al. 2007. Características produtivas do tomateiro submetido a diferentes níveis de sais, na água de irrigação. Revista Brasileira de Engenharia Agrícola e Ambiental 11: 11-16. 
OLIVEIRA JG. 2005. Estresse luminoso: uma abordagem a partir de variáveis de fluorescência da clorofila a. In: NOGUEIRA RJMC et al. (Ed.). Estresses ambientais: danos e benefícios em plantas. Recife: UFRPE. p.182-191.

PRASAD TK et al. 1994. Evident for chilling-induced oxidative stress in maize seedlings and a regulatory role for hydrogen peroxide. The Plant Cell 6: 65-74.

PRIOR LD et al. 1992. Sodium chlorine and soil texture interactions in irrigated field growth sultana grapevines II. Plant mineral content, growth and physiology. Australian Journal of Agricultural Research 43: 1051-1066.

RAJASEKARAN LR et al. 2000. Physiological mechanism of tolerance of Lycopersicon spp. exposed to salt stress. Canadian Journal of Plant Science 80: 151-159.

SANTA-CRUZ A et al. 1998. Polyamines as short-term salt tolerance traits in tomato. Plant Science 138: 9-16.

TÁVORA FJAF et al. 2001. Crescimento e relações hídricas em plantas de goiabeira submetidas a estresse salino com $\mathrm{NaCl}$. Revista Brasileira de Fruticultura 23: 441-446.

THOMAS FM \& GAUSLING T. 2000. Morphological and physiological responses of oak seedlings (Quercus petraea and Q. robur) to moderate drought. Annals of Forest Science 57: 325-333.

TORELLO WA \& RICE LA. 1986. Effects of $\mathrm{NaCl}$ stress on proline and cation accumulation in salt sensitive and tolerant turfgrasses. Plant and Soil 93: 241- 247.

VIANA SBA et al. 2004. Índices morfofisiológicos e de produção de alface sob estresse salino. Revista Brasileira de Engenharia Agrícola e Ambiental 8: 23-30.

ZHU JK. 2001. Plant salt tolerance. Trends in Plant Science 6: 66-71. 